\title{
ANTIBACTERIAL, ANTIOXIDANT ACTIVITIES AND ASSOCIATION AMONG PLANT GROWTH RELATED TRAITS OF LEPIDIUM DRABA
}

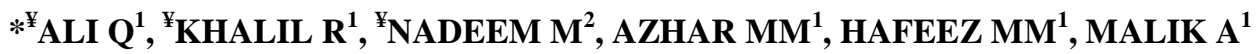 \\ ${ }^{1}$ Institute of Molecular Biology and Biotechnology, The University of Lahore, Lahore, Pakistan \\ ${ }^{2}$ Wheat Research Institute, Ayub Agriculture Research Institute Faisalabad, Pakistan \\ ${ }^{*}$ Authors contributed equally to perform research work \\ *Corresponding author: saim1692@gmail.com
}

(Received, $5^{\text {th }}$ March 2020, Accepted $10^{\text {th }}$ June 2020)

\begin{abstract}
The Lepidium draba or white tope also known as hoary cress belongs to family Brassicaceae, has been known as one of the perennial herbs which grow normally from seeds and also produced horizontal long creeping roots. It normally grows as a weed plant in farm fields. The present study was conducted to find out the antibacterial and antioxidant activities along with the plant traits of Lepidium draba. The shoot, root and inflorescence extracts were taken through using ethanol, water and n-hexan as extraction solvents. It was found from our studies that the plant extracts were heaving alkaloids, saponins, flavonoids, coumarins, anthocyans, quinons, steroids, sterols and terpenoids as potential phenolic compounds. The bacterial strains including Escherichia coli, Klebsiella pneumonia and Staphylococcus aureus were cultured to access the antibacterial activities of plant extracts. The higher antibacterial activity was reported from n-hexan extract which indicate that the $n$-hexan extract may be used for extracting phytochemicals to be used as potential antibacterial biomedicines. The water extract showed higher antioxidant activities as compared with ethanol and n-hexan extracts which indicated that the use of water extract may be as a useful antioxidant under stress conditions, may also have anticancer activities. The lower coefficient of variation was recorded for all of the studied traits which indicated the consistency of results and reliability of selecting plants from various locations. There was significant and positive correlation among plant height with inflorescence weight, leaf area and leaf length, the inflorescence weight showed positive correlation with plant height, lea length and leaf area. There was higher contribution of plant height while leaf area contributed lower and negatively towards fresh plant weight. We have concluded from our study that the Lepidium draba plant extract showed antibacterial and antioxidant activities through using ethanol, water and n-hexan as extraction solvents. The significant correlation and regression associations indicated that the plants can tolerate harsh environmental conditions.
\end{abstract}

Keywords: Lepidium draba, antibacterial, antioxidant, phenols, ethanol, n-hexan, plant extract

\section{Introduction}

The Lepidium draba or white tope also known as hoary cress belongs to family Brassicaceae, has been known as one of the perennial herbs which grow normally from seeds and also produced horizontal long creeping roots (Reed, 1970). It is native to the Western Asia, North America, Eastern Europe, Algeria and rest of Africa. The combination of white top seeds and leaves have expectorant as well as purgative effects (Al-Marzoqi et al., 2015). It can grow on a various types of soil where the moisture has adequate levels, grows under wider ranges of the disturbed plant and animal habitats which are including the cultivated lands, pastures, rangelands, along the roadsides, the waste areas which are known to be particularly the thrive on irrigated land areas (Miri et al., 2013; Scurfield, 1962; Vasilakoglou et al., 2006). In past various phytochemical based studies for white top plant from all of growing continental environmental conditions have led to isolation as well as the characterization for phenols, flavonoid, saponins, sulforaphane and glycosides (Agarwal and Verma, 2011; Chyad, 2017; Fursa et al., 1970; Ouissem et al., 2018). The allelopathic (Benakashani et al., 2017; Miri et al., 2013) and the antibacterial activities of white top plant extract have been were reported by various researchers ( $\operatorname{Rad}$ et al., 2014; Sharifi-Rad et al., 2015). However, the antioxidant activities have never been reported. Our

[Citation: Ali, Q., Khalil, R., Nadeem M., Azhar, M.M., Hafeez, M.M., Malik, A. (2020). Antibacterial, antioxidant activities and association among plant growth related traits of Lepidium draba. Biol. Clin. Sci. Res. J., 2020: 11 doi: https://doi.org/10.54112/bcsrj.v2020i1.11] 
study was aimed to evaluate presence of phytochemical, antioxidant and antimicrobial activities of white top plant extracts.

\section{Materials and methods}

The plants were collected from the fields of The University of Lahore, Lahore Pakistan. The preliminary screening for secondary plant metabolites including alkaloids, saponins, flavonoids, coumarins, anthocyans, quinons, steroids, sterols and terpenoids was carried out as through phytochemical analysis methods (Harborne, 1998; Trease and Evans, 1983). The bacterial strains including Escherichia coli, Klebsiella pneumonia and Staphylococcus aureus were cultured to access the antibacterial activities of plant extracts. The antioxidant activities were also recorded form plant extracts. Ethanol, distilled water and n-hexan solvents were used for plant extraction. The data of morphological traits including dry plant weight (DPW), fresh plant weight, leaf length, plant height, inflorescence weight and leaf area were calculated and statistically analyzed for analysis of variance, correlation and regression for studied traits.

\section{Results and discussions}

It was found from results shown in table 1 that there was presence of various phytochemical in Lepidium draba plant. The alkaloids, coumarins, sterols, quinons and terpenoids were detected from all of three ethanol, water and n-hexan extracts. The ethanol extract showed the presence of flavonoids, tannins and leucoanthocyans while water extracts showed presence of saponins, triterpenoids and anthocyans, and n-hexan extract showed the presence of flavonoids and leucoanthocyans. The presence of polyphenols like alkaloids, tennis, terpenoids and flavonoids indicated that the Lepidium draba plant has phytochemicals which have antibacterial as well as antioxidant activities, the extracted biochemicals may be used as potential medicines as antibacterial and anticancer agents (Benakashani et al., 2017; Chyad, 2017). The antibacterial activities were also observed from extracts of Lepidium draba plant (Table 2). The results form table 2 indicated that the ethanol extract showed higher anti bacterial activities against $K$. pneumonia $(10.23 \mathrm{~mm})$ followed by $S$. aureus $(9.8 \mathrm{~mm})$ and $E$. coli with $9.12 \mathrm{~mm}$ growth inhibition zone. The water extract showed higher anti bacterial activities against $K$. pneumonia $(8.73 \mathrm{~mm})$ followed by $S$. aureus $(9.13 \mathrm{~mm})$ and $E$. coli with $7.12 \mathrm{~mm}$ growth inhibition zone while the n-hexan extract showed higher anti bacterial activities against $K$. pneumonia $(11.2 \mathrm{~mm})$ followed by $S$. aureus $(10.13 \mathrm{~mm})$ and $E$. coli with $9.87 \mathrm{~mm}$ growth inhibition zone. The results showed that the higher antibacterial activity was reported from n-hexan extract which indicate that the $\mathrm{n}$-hexan extract may be used for extracting phytochemicals to be used as potential antibacterial biomedicines (Ouissem et al., 2018; Roughani et al., 2018; Sharifi-Rad et al., 2015). The antioxidant activities of different plant part extracts were also studies as shown in table 3. It was found from results that the ethanol extract from shoot (0.897), root (0.435) and inflorescence (0.792) showed antioxidant activities, the water extract from shoot (1.204), root (1.0.72) and inflorescence (0.984) showed relative higher antioxidant activities as compared with ethanol extract while the n-hexan extract from shoot (0.967), root (0.953) and inflorescence (1.0.48) showed antioxidant activities. The results showed that the antioxidant activity from shoots, roots and inflorescence parts of Lepidium draba plant. The water extract showed higher antioxidant activities as compared with ethanol and n-hexan extracts which indicated that the use of water extract may be as a useful antioxidant under stress conditions, may also have anticancer activities (Agarwal and Verma, 2011; Miri et al., 2013; Rad et al., 2014).

Table 1. Phytochemical composition of white top plant extract

\begin{tabular}{|c|c|c|c|}
\hline Phytochemical & $\begin{array}{c}\text { Ethanol } \\
\text { extract }\end{array}$ & $\begin{array}{c}\text { Water } \\
\text { extract }\end{array}$ & $\begin{array}{c}\text { n-hexan } \\
\text { extract }\end{array}$ \\
\hline Alkaloids & + & + & + \\
\hline Coumarins & + & + & + \\
\hline Saponins & - & + & + \\
\hline Flavonoids & + & - & + \\
\hline Tannins & + & - & - \\
\hline Sterols & + & + & + \\
\hline Quinons & + & + & + \\
\hline Triterpenoids & - & + & - \\
\hline Anthocyans & - & + & - \\
\hline Leucoanthocyans & + & - & + \\
\hline Terpenoids & + & + & + \\
\hline \multicolumn{4}{|c|}{$\begin{array}{c}\text { Table 2. Antibacterial activities of white top plant } \\
\text { extract }\end{array}$} \\
\hline $\begin{array}{l}\text { Bacterial } \\
\text { strain }\end{array}$ & $\begin{array}{l}\text { Ethanol } \\
\text { extract } \\
\text { inhibition } \\
\text { zone } \\
(\mathbf{m m}) \\
\end{array}$ & $\begin{array}{l}\text { Water } \\
\text { extract } \\
\text { inhibition } \\
\text { zone } \\
(\mathrm{mm})\end{array}$ & $\begin{array}{l}\text { n-hexan } \\
\text { extract } \\
\text { inhibition } \\
\text { zone } \\
(\mathrm{mm}) \\
\end{array}$ \\
\hline $\begin{array}{l}\text { Escherichia } \\
\text { coli }\end{array}$ & 9.12 & 7.12 & 9.87 \\
\hline $\begin{array}{l}\text { Klebsiella } \\
\text { pneumonia }\end{array}$ & 10.23 & 8.73 & 11.2 \\
\hline $\begin{array}{l}\text { Staphylococcus } \\
\text { aureus }\end{array}$ & 9.8 & 9.13 & 10.13 \\
\hline
\end{tabular}

Table 3. Antioxidant activities of white top plant extract

[Citation: Ali, Q., Khalil, R., Nadeem M., Azhar, M.M., Hafeez, M.M., Malik, A. (2020). Antibacterial, antioxidant activities and association among plant growth related traits of Lepidium draba. Biol. Clin. Sci. Res. J., 2020: 11 doi: https://doi.org/10.54112/bcsrj.v2020i1.11] 


\begin{tabular}{llll}
\hline Plant part & $\begin{array}{l}\text { Ethanol } \\
\text { extract }\end{array}$ & $\begin{array}{l}\text { Water } \\
\text { extract }\end{array}$ & $\begin{array}{l}\text { n-hexan } \\
\text { extract }\end{array}$ \\
\hline Shoots & 0.897 & 1.204 & 0.967 \\
Roots & 0.435 & 1.072 & 0.953 \\
Inflorescence & 0.792 & 0.984 & 1.048 \\
\hline
\end{tabular}

The results from table 4 indicated that the data was recorded for dry plant weight, fresh plant weight, leaf length, plant height, inflorescence weight and leaf area which was subjected for analysis of variance. The results showed there were significant difference among plants, area and interaction of plant and area of collection for samples. The average dry plant weight was recorded as $0.083 \pm 0.0002 \mathrm{~kg}$, fresh plant weight $\quad(0.333 \pm 0.013 \mathrm{~kg})$, leaf length $(18.956 \pm 0.824 \mathrm{~cm})$, plant height $(963.111 \pm 2.245 \mathrm{~cm})$, inflorescence weight $(3.3952 \pm 0.155 \mathrm{~g})$ and leaf area $\left(54.2132 \pm 2.4231 \mathrm{~cm}^{2}\right)$. The lower coefficient of variation was recorded for all of the studied traits which indicated the consistency of results and reliability of selecting plants from various locations (Ali et al., 2013; Ali et al., 2016; Ali et al., 2014; Usman et al., 2012). The higher plant height and inflorescence weight indicated that the plants showed potential resistance against harsh and changing environmental conditions. The results from table 5 that the higher plant height was recorded for plant 1 $(73.00 \mathrm{~cm})$ while higher plant height was recorded under the area $1(91.00 \mathrm{~cm})$ as compared with plant 2 and 3 relatively with area of collections 2 and 3 respectively. The higher inflorescence weight was recorded for plant 3 (4.04g) while inflorescence weight was recorded under the area $3(3.20 \mathrm{~g})$ as compared with plant 2 and 1 relatively with area of collections 2 and 1 respectively. The higher inflorescence weight indicated that the plant have ability to withstand under harsh environmental conditions. The higher leaf length was recorded for plant $1(19.00 \mathrm{~cm})$ while higher leaf length was recorded under the area $3(20.00 \mathrm{~cm})$ as compared with plant 2 and 3 relatively with area of collections 2 and 1 respectively. The higher dry plant weight was recorded for plant $1(0.07 \mathrm{~kg})$ while higher dry plant weight was recorded under the area $1(0.11 \mathrm{~kg})$ as compared with plant 2 and 3 relatively with area of collections 2 and 3 respectively. The higher leaf area was recorded for plant $1\left(57.00 \mathrm{~cm}^{2}\right)$ while higher leaf area was recorded under the area $3\left(60.00 \mathrm{~cm}^{2}\right)$ as compared with plant 2 and 3 relatively with area of collections 2 and 1 respectively while the higher fresh plant weight was recorded for plant $3(0.400 \mathrm{~kg})$ and higher fresh plant weight was recorded under the area $1(0.38 \mathrm{~kg})$ as compared with plant 2 and 3 relatively with area of collections 2 and 1 respectively. The higher plant fresh and dry weights indicated that the plant have higher water stress tolerance and higher photosynthetic rate to increase plant growth and productivity which may lead towards the increasing survival of Lepidium draba plant even under harsh conditions (Mahmood et al., 2015; Mobeen et al., 2015; Sadia et al., 2015).

Table 4. Analysis of variance for morphological traits of white top

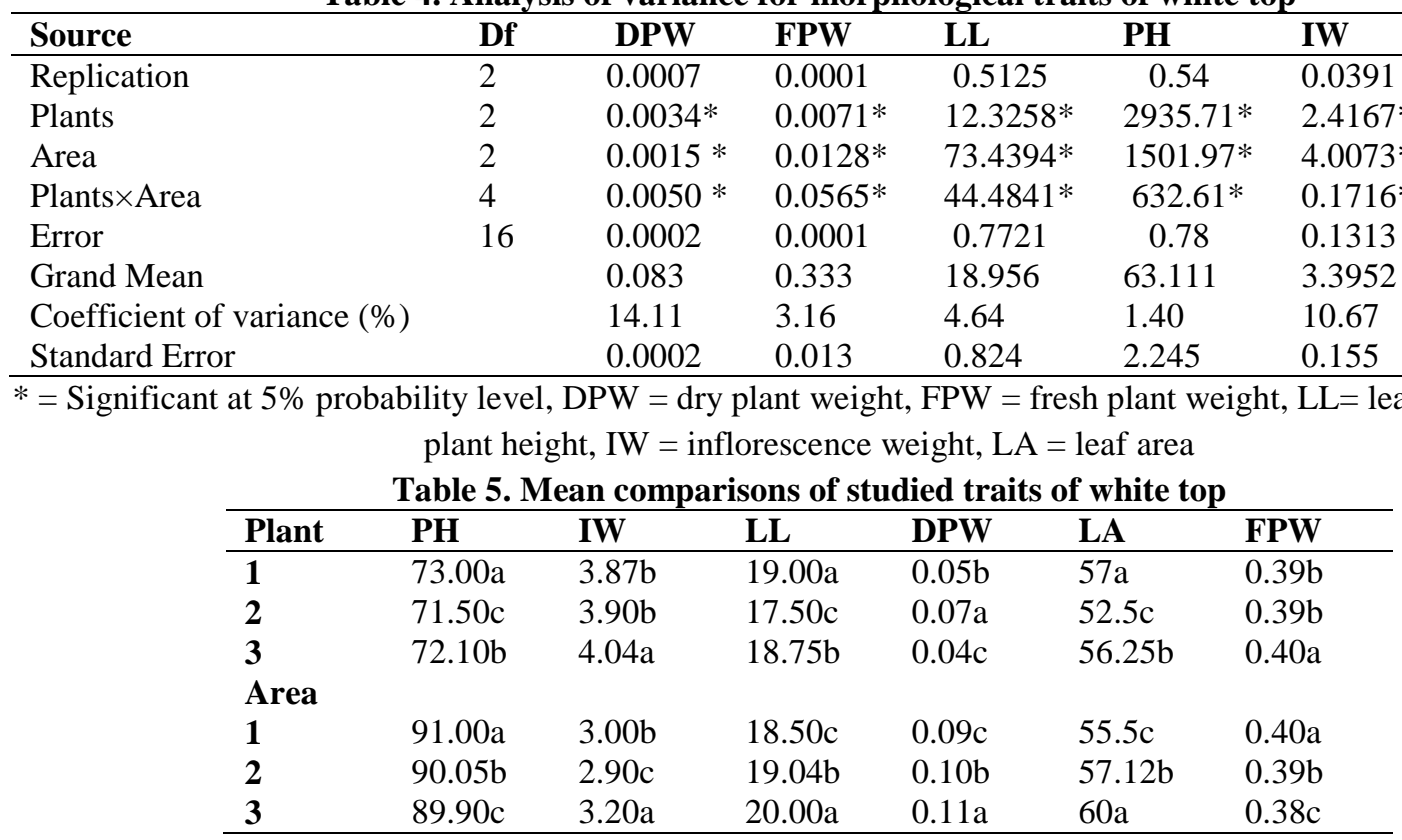

$\mathrm{DPW}=$ dry plant weight, FPW = fresh plant weight, $\mathrm{LL}=$ leaf length, $\mathrm{PH}=$ plant height, $\mathrm{IW}=$ inflorescence weight, $\mathrm{LA}=$ leaf area

[Citation: Ali, Q., Khalil, R., Nadeem M., Azhar, M.M., Hafeez, M.M., Malik, A. (2020). Antibacterial, antioxidant activities and association among plant growth related traits of Lepidium draba. Biol. Clin. Sci. Res. J., 2020: 11 doi: https://doi.org/10.54112/bcsrj.v2020i1.11] 
The correlation and regression analysis were carried out to find out the relationship among studied traits and contribution of independent variables for fresh plant weight. It was found from results shown in table 6 that there was significant and positive correlation among plant height with inflorescence weight, leaf area and leaf length, the inflorescence weight showed positive correlation with plant height, lea length and leaf area. The dry and fresh plant weights showed positive and significant correlations among them. A negative and significant correlation was reported between leaf area and dry plant weight.
The positive and significant correlations among traits indicated that the plants will have ability to combat with harsh environmental conditions. The significant and positive correlation between leaf area, inflorescence weight and plant height indicated that the photosynthetic rate may be higher which lead towards the increase in the accumulation of organic compounds in plant body which became the cause of increase in biomass of plant under stress conditions hence increase the survival rate of plant species (Ali et al., 2016; Anwer et al., 2015; Sadia et al., 2015; Zameer et al., 2015).

Table 6. Correlation among morphological traits of white top

\begin{tabular}{llllll}
\hline Traits & PH & IW & LL & DPW & LA \\
\hline IW & $0.6076^{*}$ & & & & \\
LL & $0.3357^{*}$ & $0.4789^{*}$ & & & \\
DPW & -0.0909 & -0.0258 & $-0.3739^{*}$ & & \\
LA & $0.3357^{*}$ & $0.4783^{*}$ & $0.9876^{*}$ & $-0.3739^{*}$ & \\
FPW & -0.0066 & 0.0965 & -0.2878 & $0.7948^{*}$ & -0.2878 \\
\hline
\end{tabular}

* = Significant at $5 \%$ probability level, DPW = dry plant weight, FPW $=$ fresh plant weight, $\mathrm{LL}=$ leaf length, $\mathrm{PH}=$ plant height, IW = inflorescence weight, LA = leaf area

Table 7. Regression analysis for fresh plant weight among morphological traits of white top

\begin{tabular}{lllllll}
\hline Traits & Coefficients & $\begin{array}{l}\text { Standard } \\
\text { Error }\end{array}$ & t Stat & Partial $\mathbf{R}^{\mathbf{2}}$ & $\begin{array}{l}\text { Lower } \\
\mathbf{9 5 \%}\end{array}$ & $\begin{array}{l}\text { Upper } \\
\mathbf{9 5 \%}\end{array}$ \\
\hline PH & 6.034 & 0.0008 & -0.0351 & 0.9723 & -0.0016 & 0.0016 \\
IW & 0.0201 & 0.0228 & 0.8829 & 0.3868 & -0.0271 & 0.0674 \\
LL & 1.5430 & 0.0902 & 1.3619 & 0.1870 & -0.0642 & 0.3099 \\
DPW & 2.1813 & 0.3932 & 5.5477 & 0.0000 & 1.3659 & 2.9967 \\
LA & -0.0006 & 0.0014 & -0.4504 & 0.6568 & -0.0036 & 0.0023 \\
\hline
\end{tabular}

$\mathrm{Y}=0.1228$, Multiple $\mathrm{R}^{2}=0.8054, \mathrm{R}^{2}=0.6487$, Adjusted $\mathrm{R}^{2}=0.5394$, Standard Error $=0.0654, \mathrm{DPW}=\mathrm{dry}$ plant weight, FPW = fresh plant weight, $\mathrm{LL}=$ leaf length, $\mathrm{PH}=$ plant height, $\mathrm{IW}=$ inflorescence weight, $\mathrm{LA}=$ leaf area

It was revealed from table 7 that there was higher contribution of plant height (6.034) followed by dry plant weight (2.1813), leaf length (1.5430), inflorescence weight (0.0201) while leaf area (0.0006) contributed negatively towards fresh plant weight. the coefficient of determination $80.54 \%$ was found higher which indicated that the selection of plant with higher survival rate will be helpful for increasing plant population and productivity over different locations and time zones (Ali et al., 2016; Mahmood et al., 2015; Sadia et al., 2015). The regression equation was predicted as $\mathrm{Y}=6.034 \mathrm{PH}+$ $0.0201 \mathrm{IW}+1.5430 \mathrm{LL}+2.1813 \mathrm{DPW}-0.0006 \mathrm{LA}$

\section{Conclusions}

We have concluded from our study that the Lepidium draba plant extract showed antibacterial and antioxidant activities through using ethanol, water and n-hexan as extraction solvents. The plant extracts may be used as potential medicines. The significant correlation and regression associations indicated that the plants can tolerate harsh environmental conditions.

\section{Conflict of interest}

The authors declared absence of any potential conflict of interest for manuscript publication.

\section{References}

Agarwal, J., and Verma, D. (2011). Antioxidative activity and flavonoid composition from Lepidium sativum. Nat. Sci 9, 21-25.

Al-Marzoqi, A. H., Al-Khafaji, K. R., and Kadhim, A. (2015). Influence of the crude Phenolic, Alkaloid and Terpenoid compounds extracts of Cardaria draba (Lepidium draba L.) on Human Pathogenic Bacteria. World Journal of Pharmaceutical Research 4, 456-460.

Ali, Q., Ahsan, M., Ali, F., Aslam, M., Khan, N. H., Munzoor, M., Mustafa, H. S. B., and Muhammad, S. (2013). Heritability, heterosis

[Citation: Ali, Q., Khalil, R., Nadeem M., Azhar, M.M., Hafeez, M.M., Malik, A. (2020). Antibacterial, antioxidant activities and association among plant growth related traits of Lepidium draba. Biol. Clin. Sci. Res. J., 2020: 11 doi: https://doi.org/10.54112/bcsrj.v2020i1.11] 
and heterobeltiosis studies for morphological traits of maize (Zea mays L.) seedlings. Advancements in Life sciences 1.

Ali, Q., Ahsan, M., Kanwal, N., Ali, F., Ali, A., Ahmed, W., Ishfaq, M., and Saleem, M. (2016). Screening for drought tolerance: comparison of maize hybrids under water deficit condition. Advancements in Life Sciences 3, 51-58.

Ali, Q., Ali, A., Ahsan, M., Nasir, I. A., Abbas, H. G., and Ashraf, M. A. (2014). Linex Tester analysis for morpho-physiological traits of Zea mays L seedlings. Advancements in Life sciences 1, 242-253.

Anwer, S., Ali, Q., Ali, M., Khalid, H., Ahmad, A., Ali, A., Shafiq, M., Haider, M., Nasir, I., and Husnain, T. (2015). Assessment of association among various morphological traits of Euphorbia granulata, Euphorbia hirta, Fumaria indica and Parthenium hysterophorus. Nature and Science 13, 47-51.

Benakashani, F., Allafchian, A., and Jalali, S. A. H. (2017). Green synthesis, characterization and antibacterial activity of silver nanoparticles from root extract of Lepidium draba weed. Green chemistry letters and reviews 10, 324-330.

Chyad, A. (2017). Evaluation of anticancer, analgesic and anti-inflammatory activities of the ethanolic extract of Lepidium draba Linn. leaves. $A d v$. Anim. Vet. Sci 5, 7-13.

Fursa, N., Litvinenko, V., and KRIVENCUK, P. (1970). Flavonol glycosides in Lepidium latifolium and L. draba. Rastitel'nye Resursy 6 , 567-71.

Harborne, A. (1998). "Phytochemical methods a guide to modern techniques of plant analysis," springer science \& business media.

Mahmood, S., Ali, Q., Ahmad, A., Ali, A., Babar, Y., Samiullah, T. R., Azam, S., Saeed, A., Qurat-ulAin Sajid, F. A., and Anjum, A. (2015). Estimation of correlation among various morphological traits of Carthamus oxycantha, Cirsium arvense, Cleome viscose and Convolvulus arvensis. World Rural Observations 7, 42-46.

Miri, A., Rad, J. S., Rad, M. S., and Silva, J. (2013). Allelopathic activity of medical plant, Cardaria draba (Lepidium draba L.). Annals of Biological Research 4, 76-79.

Mobeen, A., Qurban, A., Sadia, A., Harrem, K., Ali, A., Arfan, A., Muhammad, S., Muhammad, S., Idrees, A., and Tayyab, H. (2015). Estimation of Correlation among various morphological traits of Coronopus didymus, Euphorbia helioscopia,
Cyperus difformis and Aristida adscensionis. $N Y$ Sci J 8, 47.52.

Ouissem, B. S., Sabrina, B., Lotfi, B., Khellaf, R., Chawki, B., Ibrahim, D., Samir, B., and Fadila, B. (2018). HPLC Analysis and Antioxidant Properties of Algerian Lepidium draba Ethyl acetate Extract. Journal of Biologically Active Products from Nature 8, 265-271.

Rad, J. S., Rad, M. S., and da Silva, J. A. T. (2014). Evaluation of allelopathic effects of methanolic extracts from Salicornia herbacea seed and leaves on germination and seedling growth in vitro of two medicinal plants and two weeds. Environmental and Experimental Biology 12, 8387.

Reed, C. F. (1970). "Selected weeds of the United States," US Department of Agriculture.

Roughani, A., Miri, S. M., Hassandokht, M. R., Moradi, P., and Abdossi, V. (2018). Morphological variation of some Lepidium draba and L. latifolium populations. Taiwania 63.

Sadia, A., Qurban, A., Mobeen, A., Harrem, K., Ali, A., Arfan, A., Muhammad, S., Muhammad, S., Idrees, A., and Tayyab, H. (2015). Assessment of association among various morphological traits of Euphorbia granulata, Euphorbia hirta, Fumaria indica and Parthenium hysterophorus. Nat Sci 13, 47-51.

Scurfield, G. (1962). Cardaria Draba (L.) Desv. Journal of Ecology 50, 489-499.

Sharifi-Rad, J., Hoseini-Alfatemi, S. M., Sharifi-Rad, M., da Silva, J. A. T., Rokni, M., and SharifiRad, M. (2015). Evaluation of biological activity and phenolic compounds of Cardaria draba (L.) extracts. J. Biol. Today's World 4, 180-189.

Trease, G., and Evans, W. (1983). Textbook of Pharmacognosy. (Balliere. Tindall, London, 5759.

Usman, S., Qurban, A., Naveed, M., and Muhammad, S. (2012). Correlation analysis of seed yield and its components in chickpea (Cicer arietinum L.) genotypes. International Journal for Agro Veterinary and Medical Sciences (IJAVMS) 6, 269-276.

Vasilakoglou, I. B., Dhima, K., and Eleftherohorinos, I. (2006). Hoary cress (Cardaria draba) control in winter wheat with postemergence herbicides. Weed technology 20, 585-592.

Zameer, M., Munawar, S., Tabassum, B., Ali, Q., Shahid, N., Saadat, H. B., and Sana, S. (2015). Appraisal of various floral species biodiversity

[Citation: Ali, Q., Khalil, R., Nadeem M., Azhar, M.M., Hafeez, M.M., Malik, A. (2020). Antibacterial, antioxidant activities and association among plant growth related traits of Lepidium draba. Biol. Clin. Sci. Res. J., 2020: 11 doi: https://doi.org/10.54112/bcsrj.v2020i1.11] 
from Iskandarabad, Pakistan. Life Sci J 12, 7787.

\section{(c) (i) (5)}

Open Access This article is licensed under a Creative Commons Attribution 4.0 International License, which permits use, sharing, adaptation, distribution and reproduction in any medium or format, as long as you give appropriate credit to the original author(s) and the source, provide a link to the Creative Commons licence, and indicate if changes were made. The images or other third party material in this article are included in the article's Creative Commons licence, unless indicated otherwise in a credit line to the material. If material is not included in the article's Creative Commons licence and your intended use is not permitted by statutory regulation or exceeds the permitted use, you will need to obtain permission directly from the copyright holder. To view a copy of this licence, visit http://creativecommons.org/licen ses/by/4.0/.

(C) The Author(s) 2021

[Citation: Ali, Q., Khalil, R., Nadeem M., Azhar, M.M., Hafeez, M.M., Malik, A. (2020). Antibacterial, antioxidant activities and association among plant growth related traits of Lepidium draba. Biol. Clin. Sci. Res. J., 2020: 11 doi: https://doi.org/10.54112/bcsrj.v2020i1.11] 